\title{
Blind Technology Transfer or Technological Knowledge Leakage: a Case Study from the South
}

\author{
Darío Gabriel Codner', Paulina Becerra², Alberto Díaz
}

\begin{abstract}
Blurring boundaries between science and technology is a new phenomenon especially in fields such as biotechnology. The present work shows the fate of biotech research papers on foreign patents produced during the last decade in Quilmes National University. It aims at recognizing the flow of scientific knowledge developed at a public university towards foreign companies and organizations as well as reflecting on its technological value, the role of technology transfer management, the institutional significance of technology transfer processes and the need to develop innovative public policies for solving structural failures caused by industrial underdevelopment.
\end{abstract}

Keywords: patents; technological transfer; citation analysis; university policies; scientific research

\footnotetext{
'Subsecretario de Investigación y Trasnferencia, Universidad Nacional de Quilmes. Roque Saenz Peña 352 Bernal - Provincia de Buenos Aires (BI876BXD).Argentina.Tel/fax: 54 II 4365-7I00 ext.4I8I.E mail: dcodner@unq.edu.ar

${ }^{2}$ Facultad de Arquitectura, Diseño y Urbanismo. Universidad de Buenos Aires. Intendente Güiraldes 2160. Pabellón III Ciudad Universitaria (CI428EGA) - Buenos Aires. República Argentina.Tel: 54 II 4789-6200 E mail: pbecerra@fadu.uba.ar ${ }^{3}$ Director del Centro de Investigación y Desarrollo en Biotecnología Industrial. INTI.Av Gral. Paz 5445- Edifico 5I - Casilla de Correo I57- (BI650WAB) San Martín Provincia de Buenos Aires,Argentina Tel.: 54 II 47246448. E mail:adiaz@inti.gob.ar
} 


\section{Introduction}

The last years have been characterized by an accelerated transforming process of the cultural, economic, political and social dimensions of society. This brought about a series of radical changes in production methods which gave rise to the knowledge society ${ }^{4}$ where knowledge itself becomes the main factor for explaining economic growth along with capital and labor. In this sense, major relevance is given to the production of knowledge-intensive goods and services. This scenery results from a completely new way of generating knowledge where expectations for applying research results and development become part of the faculty agenda (Gibbons, 1997). This determines a new pattern in the search for practical results, complex problems solved through interdisciplinary work and the adoption of new ways of organizing through a high diversity of actors.

In economic terms, innovation becomes the main activity and its sources fade while organizations reconfigure themselves in search for it as a mechanism to develop their competitiveness (David and Foray, 2002). This transformation emerges from leaving aside the conception of innovation as a context-independent individual decision process, in favor of a conception with actors embedded in different institutional networks (Nelson \& Winter, 1982; Nelson, 1993, 1995; Lundvall, 1985; David \& Foray, 2002; Teubal, 1996; Freeman, 1982, 1987; among others). The efforts to discover and understand association phenomena between scientifictechnological capabilities and innovation processes with agents who behave according to market and state incentives have fostered the conceptualization of the National Innovation System (NIS) as a paradigm for designing public policies for science, technology and innovation. Additionally, the systemic conceptualization of Sabato Triangle (Sábato \& Botana, 1970) and Triple Helix (Etzkowitz \& Leydesdorff, 1996) emphasizes the importance of interactions among universities, companies and the government in order to achieve system stability and virtuosity, in accordance to new complex models which explain the innovative process (Kline-Rosenberg, 1986). Nowadays there is a strong tendency to link innovation with manufacturing, specially in biomanufacturing (E. B. Reynolds: Innovation, Production and Sustaintable Job Creation: Reviving U.S. Prosperity - from MIT Industrial Performance Center - February 2012).

'The names and approaches about this new stage were diverse: Knowledge Society (Drucker, 1969); Knowledge Era (Castells, 1996); Economics of Knowledge (OCDE); Post-industrial Society (Bell, 1973); Control Societies (Delleuze); Cognitive Capitalism (Roullani et al, 2004); Informational Capitalism (Zukerfeld, 2010) etc.
In short, from the conceptual point of view the lineal model in which knowledge and technology transfer was performed as a single flow from basic research to innovation, was left aside. In accordance to this phenomenon, during the last years, new trends have emerged (especially developed by large and medium size companies) which support the business strategy oriented towards innovation through partnership with external research groups (coming from the scientific and technological system) under a new conceptual framework: the open innovation (Chesbrough, 2003). This approach has particular relevance in some disciplinary fields such as biotechnology in which boundaries between basic science and technology have "blurred", causing an intense interaction between companies and the university research system (Pisano, 2006).

On the other side, the systemic character of innovation places the problem of knowledge appraisal as a core issue. In this way, intellectual property (IP) becomes the focus of some business strategies in order to improve or maintain their competitiveness, while for scientific and technological organizations IP represents an effort to control and ensure knowledge transfer from R\&D labs, especially in developing countries.

The interaction between intellectual property rights and the mechanisms for developing scientific and technological knowledge has been a fertile ground for economic and political debate.A milestone in this dynamics has been reached thirty years ago with the adoption of Bayh-Dole Act in the United States which did not establish a valid legal framework for other regions, but which has been considered the most relevant precedent as regards R\&D\&i's institutional policies, extending its effect over almost the entire world. This law has allowed university research groups, public administration and private companies to economically benefit from commercializing intellectual property rights over technological developments generated from federal government funds. Under this law, those who benefited from federal funds devoted to R\&Dactivities had access to the right to patent inventions and license companies. In order to foster the exploitation of the results coming from State funded research, Bayh-Dole Act has influenced the behaviour of universities and science and technology public institutions regarding the use of patents as mechanisms for the dissemination and transfer of technology from research results. It has also encouraged discussions over intellectual property management models (Schmal R, 20I0) and the current international debate over science "privatization and commercialization" (Mirowski, 20II).

Although some studies on patents economic value show that only a few of them gain commercial value (Lanjouw J. et al 1998), the development of IP protection policies by

ISSN: 07 I8-2724. (http://www.jotmi.org)

Journal of Technology Management \& Innovation (c) Universidad Alberto Hurtado, Facultad de Economía y Negocios. 
universities is increasingly important. Many universities have developed technology transfer offices, technology commercialization offices and even companies to obtain the licensing of those patents, not only for the economic returns but also to control both knowledge and technology use and applications. This phenomenon is consistent with the emerging search for university efficiency and efficacy as regards knowledge transformation into patents. This is shown by some Brazilian studies of university patents fate (de Souza Querido et al, 20I I; Marques et al 2007) where it is stated that the best performances regarding technological appraisal of scientific knowledge is achieved in those universities where intellectual property management has gone through a process of institutionalization.

In this context, and based on the conception that patents can be necessary but not enough for the applicability of research results, the relevance and appropriateness of analyzing the correspondence between patent development and R\&Dactivities is shown. It has been recently demonstrated -within PMTIII evaluation process (Lugones, 20I I)- that in Argentina research grants assigned, on the basis of scientific quality, generates a positive effect on both quality ans amount of patent production among biomedic field projects. Furthermore, the problematization of this phenomenon appears as an opportunity to reflect on the relationship among scientific research investment, technology development processes, industrialization and innovation.

Our strategy in carrying this analysis is to identify and study scientific articles references in patents documents.According to Pisano's viewpoint (op.cit.), taking into account the large amount of reference to scientific literature in biotechnology patents, Narin and Noma (1985: 369) concluded that "the division between leading edge biotechnology and modern bioscience has almost completely disappeared". Callaert's work also provides evidence in this sense by demonstrating through statistical data the strong connection between the technological fields of chemical and pharmaceutical industries and scientific activity in terms of the importance placed on scientific papers within Non patent references intensity (Callaert 2006, op. cit.). It is precisely due to boundary blurring in this field of study that contradictions about the traditional conception of science and technology reveal themselves: science as an area of knowledge accumulation with a strong emphasis in publication, as opposed to technology focused on knowledge generated by others, which is strongly linked to the conception of property (Narin y Noma, op.cit.).

Blurring boundaries between science and technology is a new phenomenon especially in intensive fields such as biotechnology or nanotechnology. Thus, the appearance of developments based on patented scientific works becomes increasingly more frequent generating a sort of "inclusive appropriation"s (Zukerfeld, 2010) which guides the knowledge flow from universities and public institutions towards private companies without a real connection. On the other hand, the issue of local appropriation of scientific knowledge has also been broadly discussed in the Latin American context (Kreimer, 2006).

However, the focus of our work aims to reflect on both intervention strategies and tools which allow the capitalization of the value generated through R\&D developed in the public sector, without discussing wether or not knowledge must be "released", since the researcher finds himself in a constant tension between publishing -issue through which he is academically assessed- and keeping the secret in order to proctect that knowledge, which he may or not be able to turn into useful technology.

\section{Background to the study of scientific references in patents}

The study of patent documents has been used with different purposes. In general, it has been linked to a concern for quantitatively assessing science and technology contribution to economic development and also, among others, for characterizing the interaction between science, technology and industry. Particularly, we are interested in those works which have questioned the link between scientific output and technological developments - protected by patents. And, while most of them tend to analyze and characterize different ways of linking scientific to technological development activities, in some of them it is possible to find interesting issues for our analysis.

A first point of analysis is related to the structure of patent documents in which three parts may be basically observed (Ganguli and Blackman, 1995): I- cover, including title, inventors, applicants, references to other documents - mainly patents and scientific works-, and application and publication dates; 2- full text which includes a detailed description of

${ }^{2}$ Zukerfeld (2010, pp II6-120) defines Inclusive Appropriation as a regulatory modality by which capitalist companies exploit -through Intellectual Property- free knowledge, taking advantage of that production modality which concentrates itself in capitalizing unpaid knowledge production, that is to say, the one carried out outside the company business structure. Unlike the industrial production model, this procedure does not violate any law, since it is based on the exploitation of the weak -generally voluntary- exercise of intellectual property rights. While Zukerfeld introduces this concept associated to computer business, in this case it may be extrapolated to the field of biotechnology since knowledge is -voluntarily- released through the publication of papers and conference presentations. 
the invention, history, explanatory graphics and data tables; 3- claims wich establish those legal elements protected by patents. The work of Narin and Moma (op.cit), pioneer in the study of the relationship between scientific works and patents provides an initial discussion about the place where scientific references are located, distinguishing those which appear on the patent cover -included o approved by the examiner- and those which appear in the body of the text -included by the inventor or applicant.

In this sense, it is possible to differentiate between the importance of a quote appearing in either place. First, for some authors, a quote appearing on the list of references of the patent cover becomes the most important, since it means the examiner relied on those documents to establish the novelty of the invention (Narin and Noma, op.cit.). Howerver, appearing in the cover but not in the body of the patent text could mean certain bias the examiner places on the patent and not a direct link with the invention. Among their conclusions, of significant statistical value for their sample, the authors established that on the average patents, only $15 \%$ of the scientific references were included in the cover (Narin y Noma, op.cit). On the other hand, the inclusion of references in the body of the text would undoubtedly indicate having taken the quoted work as a relevant precedent for supporting the invention. This could be taken as a sign of the technological value that inventors assigned to cited knowledge, being these a key precedent to the blind technological transfer process However, it is also possible to establish different relevance levels in this last case depending on the place and way in which the quote has been written. Some of these considerations can be found in Meyer's work (2000) altough this autor focuses on the sistematization of quotes in the field of nanotechnology.

In works such as those of Perko and Narin (1997) interesting precedents about the relationship between science and technology patented in the public sector can be found by tracking quotes in US patents especially in scientific research works related to the United States Department of Agriculture (USDA). The author suggests that those scientific papers quoted in patents are a "unique" source of information about the transfer of scientific results in patented innovations. In a later work, it is stated that "it is plausible to state that more scientific references signal greater relevance or relationship between the technology at hand and scientific activity" (Callaert op.cit.). In this sense, the inclusion of a scientific paper in a patent could be understood as an indicator of the technological value of referenced research. Understanding this movement from science to industry through IP opens new opportunities and questions, since it asks whether universities and government agencies can identify potential technologies and companies with which they can cooperate and reach research and development agreements. In some way, this improves the expected usefulness of research results, that is, the analysis of scientific papers quotes in patents becomes itself a tool for technology transfer management.

From a policy analysis perspective, the work of Narin, Hamilton and Olivastro (1997) has been a great inspiration since it indicates the strong bond between public sciences for the development of technology, noting the recurring quotes to scientific papers published in a large group of patents by publicly funded institutions. Meanwhile, Krauskopf (2007) shows the importance of this type of analysis for Latin American countries as he studies the impact of scientific research carried out in Chile about technologies patented in the United States between 1984 and 2003. That paper concludes that local research is not used by the local industry, but rather the American companies have appropriated Chilean R\&D results.

In a country like Argentina which is poorly industrialized and which has especially applied liberal recepes from the ' 90 s, the role of intellectual property has not been seriously discussed yet, nor has it been its relation to industrial and innovation policies. While these discussions were valid in the '70s and ' 80 s with studies on intellectual property (Katz 1975) especially with regard to pharmaceutical industry, they did not become sectorial public policies. That is why it can be inferred that although Argentina developed an important scientific basis, especially in biomedicine, it has not make enough industrial, productive and social use of the results achieved with or without intellectual property existence. Furthermore, knowledge generated by Argentinean scientists over the last 70 years (some of which had their origin in the jobs of two first Argentinean Nobel Prizes) served as basis for some international companies to develop new medicines or vaccines in their own countries (Goldstein, 1987).

Fortunately, Argentina has seen its budget for science and technology substantially increased since 2003 and the institutional development of the science and technology system has evolved (from the creation of a Ministry of Science, Technology and Innovation in 2007). In addition, public-private partnerships under the open innovation model is also emerging incipiently (Codner and Diaz, 2009), being supported by various public instruments which promote the new Ministry of Science, Technology and Innovation. This set of political actions have affected the field of biotechnology, developing new businesses and increasing the number of patent applications (Codner, 20I I). However, there is no evidence on the relevance of knowledge transfer from the public sector to industry (Codner and Diaz, op.cit.).

Therefore, it is particularly relevant to explore the fate of biotechnology research papers produced in Argentina. Our 
hypothesis establishes that part of the local R\&D is exogenously appropriated and can be measured through the reference of scientific papers in foreign patents.

This paper seeks to explain -troughout a case study- how the scientific and technological knowledge from Quilmes National University has been flowing towards foreign organizations and companies. In this sense, it also aims at reflecting on the technological value of the produced knowledge, the role of technology transfer management and the institutional meaning of blind technology transfer processes. The approach combines both qualitative and quantitative aspects not focused on the methodological approach about patent quoting analysis. Our paper focuses on the discussion over the appropriation of technological knowledge generated by institutions engaged in scientific and technological research, especially in highly dynamic disciplinary fields such as biotechnology.

\section{Methodology and procedure}

This research is based on a sample built by identifying scientific papers written by researchers from Quilmes National University ${ }^{3}$ mentioned in patents applied from The United States and/or international context via $\mathrm{PCT}^{4}$.

Meassurement ${ }^{5}$ was performed through the Delphion platform -from Thompson Reuters (www.delphion.com)- which offers complete documents on patenting coming from the world's most important international patent databases as well as searching technology and tools for analysis with direct access to more than 54 million records.

Whole text of the patent application was scanned, as quotations can appear both on the first page as in any part of the project narrative.

At first, the full names of the researchers were searched for. Then, the scientific title of the article referenced was examined, and finally the institution was identified. This process is based on the very brief way in which scientific papers are quoted in patents, where only the initials for the author names appear next to his/her surname.

A problem posed by this methodology is the identification and verification of the quoted researchers (authors) identity

\footnotetext{
${ }^{3}$ Quilmes National University had a staff of 350 teacher-researchers and 170 scholarship holders (28\% full-time research faculty, $25 \%$ researchers able to manage projects).

${ }^{4}$ The Patent Cooperation Treaty (PCT) was developed at Washington on June 19, 1970, modified and amended last Oct. 3, 2001.

${ }^{5}$ Meassurement was carried out by Ing. Ernesto Machicote from BERKEN IP S.A. under the supervision of Darío Codner.
}

due to two issues. First, the existence of homonymous and constrains generated by the citing ways chosen by researchers regarding the fact that in general, quotes mention the name of the first author to sign the paper, which only allows the detection of just the first researcher to sign the cited paper. In this sense, there are differences between patents registered in the U.S. Patent and Trademark Office (USPTO) and in the European Patent Office (EPO) in terms of quotations contained therein due to different policies employed. Second, another methodological aspect to note is that in those papers where the quote corresponds to a leading researcher whithout explicitly mentioning the rest of the team who participated in the job, only the name of the leading researcher was taken into account. That is, measurement can be incomplete since only the author leading the job appears in the reference, for example: "Giampieri C., et al." Thus, the participation of other researchers who signed the paper other than in leading position becomes invisible.

The counting methodology was performed on one patent per family. That is, each scientific article was identified in one patent no matter where that invention had been presented. In this way duplication was avoided.

In order not to duplicate counting, it was decided to seek out the heads of R\&Dgroups. Thus, a sample of 14 researchers able to conduct R\&Dprojects in the area of biotechnology at the university was selected.

The sample resulting from this search was established in 52 patent families which quoted scientific papers written by UNQ researchers applied between 1999 and 2010 . Since the UNQ is a university founded in 1989, most of its researchers had already developed R\&Dactivities in other institutions, that is why only those 30 applications referencing scientific papers postmarked after the researchers admission to the UNQ were considered for this analysis.

This criterion was applied in order to remove those research activities developed prior to joining the UNQ and with the aim to define the sample only with data related to R\&D activities developed in the framework of this university. Although this may result an arbitrary selection, it represents an effort to identify those research results on which the university could take action at the time of implementing its intellectual property protection policies, industrial exploitation or simply its technology transfer to society.

\footnotetext{
${ }^{6} \mathrm{~A}$ patent family is the set of patent documents which share priority, that is, resulting from the same priority application.
} 


\section{Results}

On the 14 group leaders used to define the researchers sample, only 6 of them appear quoted in those 30 foreign patents that made up the final corpus for this paper. On this universe of patents, an analysis of the application documents tending to question the technological value of knowledge published by UNQ researchers was performed. This analysis yielded data regarding three different focal points: a) the time gap for the technological application of scientific knowledge; b) the institutional features of the asignees; and c) the proximity to the technological "core" protected by the patent.

\section{A - FIRST FOCAL POINT: Technological value through temporal dynamics}

The first focal point refers to the time gap between the scientific paper publication and the patent application with the paper reference.

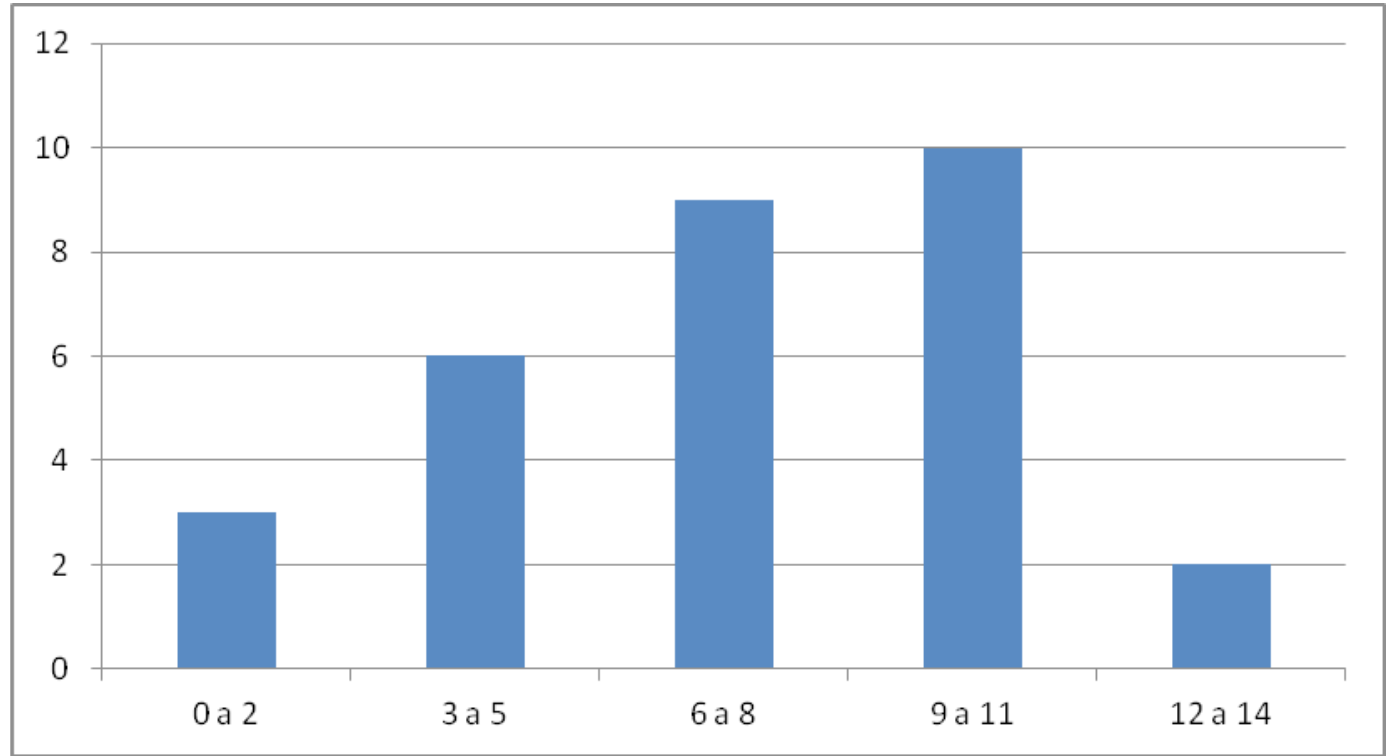

Fig. I.Time in years between paper publication and patent application

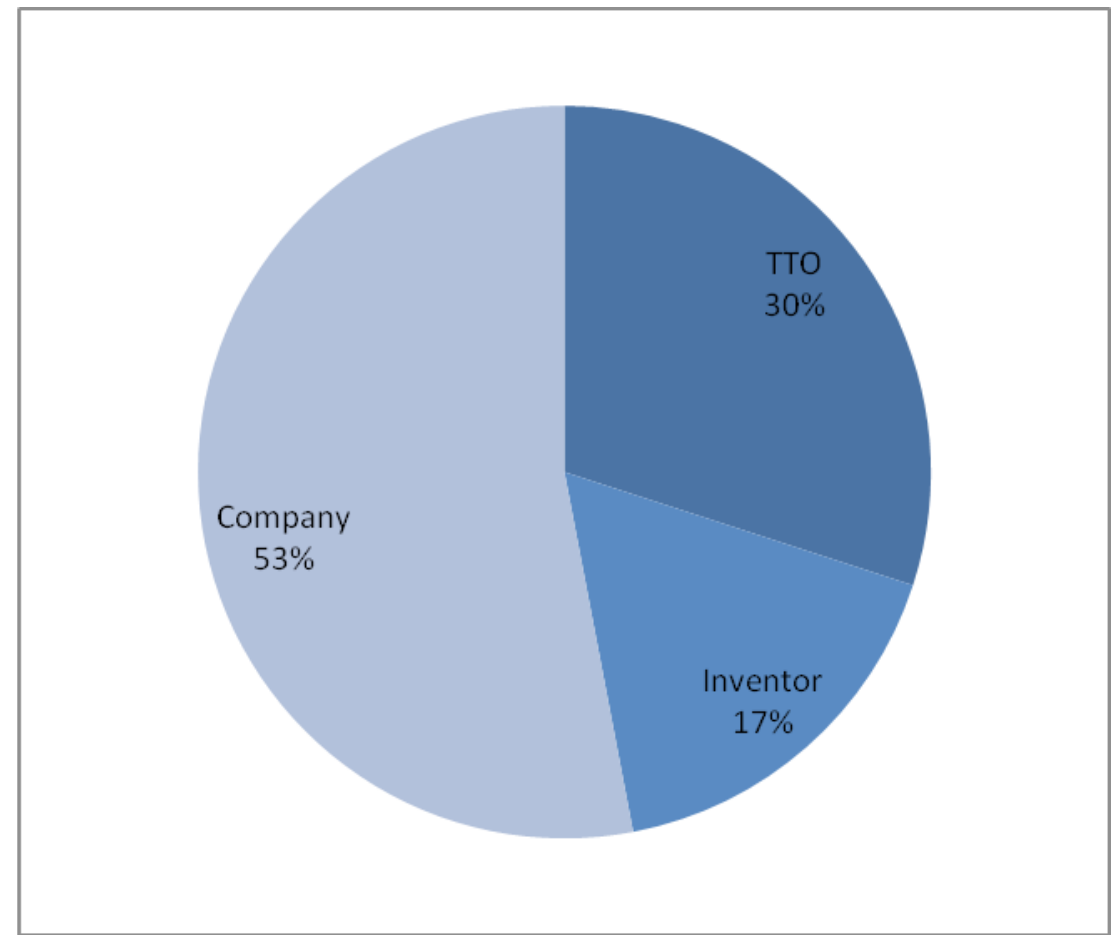

Fig.2. Assignee distribution 
In the analyzed sample the time between the scientific paper publication and the patent application is highly variable and ranges form 0 to 13 years, with a mean of 6.9 years. From a total of 30 patents, in most cases $(63 \%)$ the transfer occured between 6 and II years; it is important to note that $10 \%$ of patents have been applied within two years of the paper publication, which could result in an indicator of the technological potential of knowledge (see Fig. I).

\section{B- SECOND FOCAL POINT: technological value according to institucional features.}

This second focal point focuses on the institutional feature of the patent applicant. In this sense, three groups have been identified: applications from companies, from inventors and from public or private institutions which main activity is R\&D(see Fig. 2)

From this taxonomy it appears that $53 \%$ of examined patent applications were submitted by companies, including Bayer Schering Pharma, Aktiengesellschaft, Isis Pharmaceuticals, Trubion Pharmaceuticals, TranzymePharma Inc., Tracie Martyn International Ltd, Dionex Corporation and IPSATTherapies Oy AB and St. Jude Medical. In contrast, $30 \%$ of patents were submitted by scientific organizations or technology transfer offices. Among them, we can mention active institutions in the field of technology transfer, as Yeda
Research and Development (Waissman Institute of Israel), the University of North Carolina, Georgia State University Research Foundation, Universidad Complutense de Madrid, Tokyo University of Science Educational Foundation, University of Bristol, Stanford J. University, Parker Hughes Institute, North Shore Long Island Jewish Research Institute, MUSC Foundation for Research Development, Emory University and Dalhousie University. Finally, in the 13\% of the patents the asignees were individual inventors ${ }^{7}$.

\section{C - THIRD FOCAL POINT:Technological value ac- cording to the contribution to the invention}

The third focal point aims at highlighting the technological importance assigned to the scientific article in accordance to its contribution to the patent technological development. This analysis led to identifying three patterns which could indicate the distance between the technological core protected by the patent and the knowledge developed in the UNQ: a) integrating the state of the art, b) providing scientific evidence and c) contributing some method of production (see fig. 3).

On the one hand, $37 \%$ of the analyzed patents contain information about scientific papers as basic reference of the state of the art in which the invention was developed. For example, the invention US 2009/0 I I I I 0 A I entitled "Method

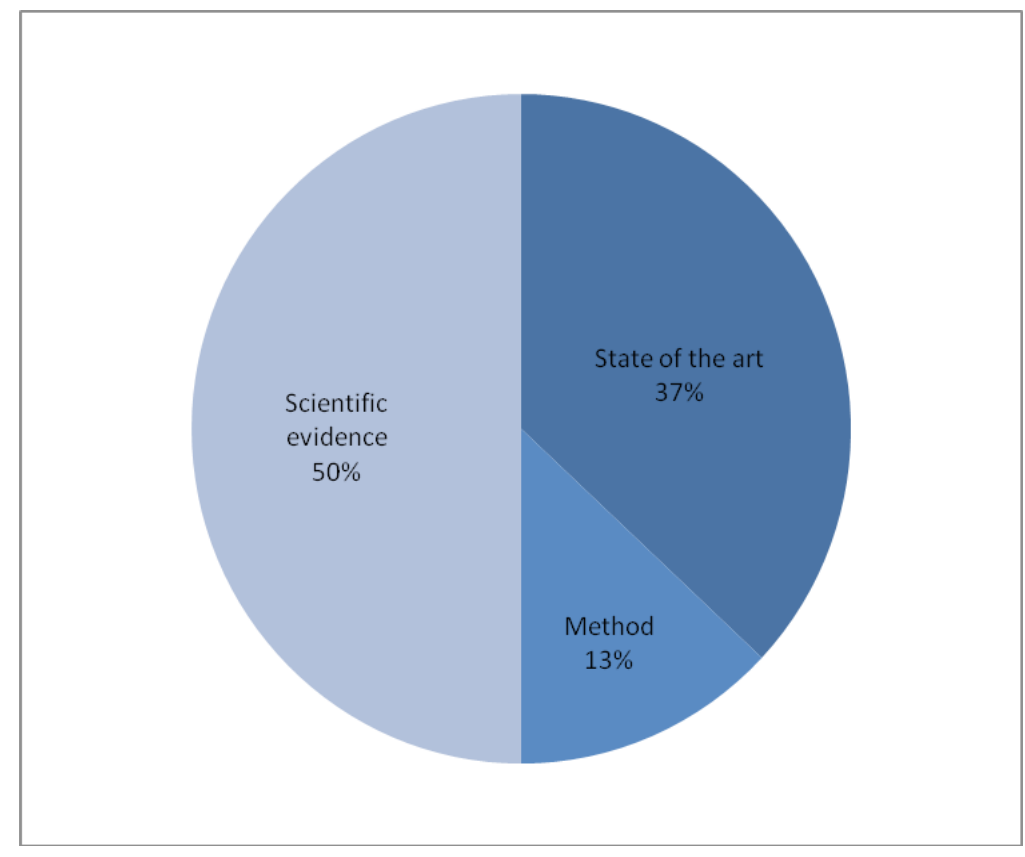

Fig.3. Distribution according to tecnology location

${ }^{7}$ The information about inventors in some cases does not allow to identify whether they belong to a particular organization or they are individuals who personally apply for the patent.

ISSN: 07 I8-2724. (http://www.jotmi.org) 
of diagnosing adolecent idiopathic scoliosis and related sindroms Rausing spinal deformities and method for screening for a compound useful in treatment of any of these diseases" on page II (REFERENCES section) describes the scientific paper without further mention.

On the other hand, $50 \%$ of the analyzed patents indicate that the papers provided scientific evidence. For example, the invention US 2009/02085I0 entitled "Antibodies and pharmaceutical compositions containing same usefulness for inhibiting activity pf metalloproteins" presents in its background a scientific evidence: "The uncontrolled breakdown of connective tissue by metalloproteases is a feature of many pathological conditions, probably resulting from an excess of MMP activity or from an imbalanced ratio between the natural MMP tissue inhibitors (TIMPs) and MMPs. TIMPs inhibit MMPs by forming stoichiometric complexes with the active zinc binding site of MMPs" drawn from the scientific paper. Finally, $13 \%$ of the analyzed patents describe the use of technological methods which determine production protocols, an example of this is the case of a paper quoted in the patent application US 6737520 B2 entitled "Oligonucleotides having A-DNA form and B-DNA form conformational geometry" in which the scientific paper is quoted as follows: :"The nucleosides were syntesized according to the procedure described by researcher..." . This may be evidence that the published knowledge contributed significantly to the technological development protected by the patent.

\section{Conclusions}

The present study focuses on reflecting upon the technological value of the knowledge generated, outlining a metrics. On the one hand, a small percentage of scientific papers were referenced in patents less than 2 years from their publication. This could be interpreted in terms of the relevance of scientific results in the technological field of the patent. One question that emerges is which institutional mechanisms should be or can be implemented to identify the opportunity provided by the publication, so as to increase the likelihood of institutional appropriation of research results.

On the other hand, three patterns of contribution of scientific knowledge to patented developments were identified: a) integrated to the state of the art; b) providing scientific evidence and c) contributing some method of production. This taxonomy must be deeply discussed since it just attempts to present an issue which requires the design of an ad-hoc metrics not described by literature yet. It is important to note that we considered the cites in the framework of methods patterns (efficency and efficacy proven procedures) and scientific evidence (empirical evidence supporting the invention) which represent a qualitatively higher instance than the state of the art pattern. This could be due to the fact that in the first two instances, the results presented by UNQ researchers represent an effort saving for the inventors since, in case those results did not exist, researchers should do the corresponding experiments to support them. On the contrary, the state of the art would represent only a framework allowing the development of experiments and/ or the establishment of the context for the field of knowledge in which the invention is developed. Our interpretation is that those papers referenced in the state of the art, do not hold any technological value by themselves. However, we must indicate that this conceptualization is not definitive but it represents a first approach towards making visible the need for developing a metris/taxonomy for assessing the technological potential of scientific research results.

Furthermore, this work shows the flow and the appropriation of scientific and technological knowledge developed in the UNQ by foreign organizations and companies, whose circulation and diffusion occurred without the university being able to control, prevent or measure it. Somehow, and using an analogy that is certainly controversial, we could characterize the diffusion of knowledge through these mechanisms as a process of "undifferentiated waste," because there is no prior identification of what can be used again or "recycled" so that actions can be implemented in order to lead that knowledge towards boosting local development, taking advantage of its value in the surrounding area.

Somehow, this sort of "liberation" of knowledge -typical of the academic logic of science- can be understood as an indirect subsidy from the Argentinean public sector to foreign companies. Being this type of phenomena invisible to the political actions of the institution, we may consider them as "blind technology transfer processes" or "just blind leakage of knowledge" - which could also be considered as "brain drain" or defined as a "brain gift". We also think that with the due variations, this happens in all S\&T institutions in the country.

In terms of implementation of innovation policies between the central countries and developing countries a centerperiphery relationship is established which, among other things, can be verified by observing the flow of knowledge from developing todeveloped countries. This was a broadly discussed issue, since 1960s, by the so called Latin American School of Thought Science and Technology (Martinez Vidal, 2002).

Therefore, it is imperative to reflect on the importance of developing a National Innovation System that can absorb some of the results of local research, either for exploitation within the country or to be effectively marketed or licensed abroad. We also face the problem of reflecting on the need to design new instruments to promote innovation which, on 
the one hand, further stimulate local industry connections with the Argentinean scientific and technological subsystem, and, on the other, control, guide and / or streamline this "invisible flow" of knowledge generated. This will require the active participation of other ministries (Health, Agriculture, particularly Industry) to complement and guide the iniciatives of the Ministry of Science, Technology and Productive Innovation.

The universities will not be able to solve the lack of an industrial sector demanding research results, but it can be a key actor in public policies for its own development (J.Vega Jurado et al, 2007; Zawislak et al., 20I I). That is why it is imperative to resignify the role of university technology transfer offices as it will be desirable to increase the likelihood of research results appropriation. This forces us to think about the institutional significance of invisible technology transfer processes by developing new strategies of knowledge appropriation and appraisal.

In this context, although there are new tensions behind patenting and / or publishing strategies, they do not appear to be in opposition, rather they complement each other. The benefits of publishing or patenting cannot be shown without an industrial system which that can appropriate the results and technologies. Patenting research results funded almost exclusively by the public sector has begun to be a "fashion" in the scientific field.A subtle tendency "to leave the laboratories", to transfer knowledge, to "do business" or take part in them has forced the discussion of this issue and encouraged the development of institutional and public policies which allow for the solution of this "structural failure".

As regards the political implications of blind technology transfer, and, from the point of view of S\&T institutions, we can identify three simultaneous lines of action.

a-The awareness of researchers, whose logic leads them to publish to grow -in recognition, funding and academically- on the issue of blind technology transfer and its implications.

b-The protection of technological knowledge as a strategy to monitor its application as regards both the context and organizations, preventing leakage of knowledge to the foreign industry;

c-The promotion of local-regional development, in order be able to appropriate the knowledge generated in the institution, and capitalize on immediate as well as long-term results. These strategies aim at increasing the likelihood of local appropriation and decreasing the opportunity to subsidize foreing industrial developments. That is, they control the fate of technological knowledge and, therefore the economic resourses invested to achieve it. For that reason, it is necessary to develop a policy oriented towards the protection and diffusion in accordance to a model of privatization and free acces to knowledge.

As it has been previously mentioned, technology transfer offices are key in the process of identifying that knowledge which can be useful or necessary for the local context, so that it can be protected and oriented towards potential beneficiaries. In this sense, knowledge transfer is no longer invisible and can be subject to strategies for institutional or territorial development. It is no longer a "undifferentiated waste".

We believe that this work represents a first effort to identify the phenomenon of blind technology transfer, and we do not consider its results as conclusive ones. On the contrary, we hope that this, as well as the following research work on the subject, let us reflect on the complexity of this problem, and help us devise better and more effective strategies for providing cross-fertilization between science, technology, industry and local development.

\section{References}

BELL, D. (1973 [2006]). El advenimiento de la sociedad postindustrial (Alianza Editorial)

CALLAERT, J., VAN LOOY, B, VERBEEK, A., DEBACKERE, K $Y$ THIJS, B. (2006) "Traces of prior art: an analysis of nonpatent references found in patent documents" en Scientometrics, Vol. 69, Nro I (2006) págs. 3 a 20.

CASTELLS M. (1996). “La red y el yo" en La Era de la Información: Economía, sociedad y cultura (Edición de Hipersociología)

CHESBROUGH, H (2003) Open Innovation: The New Imperative for Creating and Profiting from Technology. Boston: Harvard Business School Press.

CODNER D. (20II) "Capítulo IV.Alcances, resultados e impacto del FONCYT entre 2006 y 20I0" en Porta, F. y G. Lugones (directores), Investigación científica e innovación tecnológica en Argentina. Impacto de los fondos de la Agencia Nacional de Promoción Científica y Tecnológica, Bernal, Universidad Nacional de Quilmes, 20II, pp. I33-I8I.ISBN edición impresa 978-987-558-234-7. ISBN libro electrónico 978-987-558-238-5.

CODNER D. y DÍAZ A. (2009) “Biotecnología en Argentina: innovación tecnológica y sociedad. Producción y uso de conocimientos". Yale University. Law School. Information Society Project. Access to Knowledge Program. http://yaleisp. org/publications/a2kresearch/ 
DAVID P. y FORAY D. (2002). "Una introducción a la economía y a la sociedad del saber". Revista Internacional de las Ciencias Sociales. Número 171. 7-28

DE SOUZA QUERIDO A et al (20II) "What is the Destiny of Patents of Brazilian Univesities?" J. Techno.Manag.Innov. Vol 6, Issue I.

DRUCKER, P. (1969). The Age of Discontinuity Guidelines to Our Changing Society. New York: Harper \& Row.

FREEMAN, C. (1982). "Technological infrastructure and international competitiveness", draft paper submitted to the OECD ad hoc group on science, technology and competitiveness, Paris: OCDE;

FREEMAN, C. (1987). Technology policy and economic performance - lessons from Japan. London: Frances Pinter.

GANGULI, P., BLACKMAN, M.J.R., (1995). "Patent documents: a multi- edge tool.” World Patent Information 17 _4., 245-256.

GIBBONS M, et al. ( 1997 ) "La nueva producción del conocimiento" Ed. Pomares-Corredor

GOLDSTEIN, D. (1987) "Biotecnología, Universidad y Política”. Siglo XXI Ed., págs.. $199-200$.

HETZKOWITZ, H. y LEYDESDORFF, L., Eds (1997). "Universities in the Global Economy:A Triple Helix of UniversityIndustry- Government Relations", London: Casell Academic.

KATZ J. (1975)"Patentes, corporaciones multinacionales y tecnologías. Un examen crítico de la legislación internacional", cap. I2.. En J. Sábato (ed.) El pensamiento latinoamericano en la problemática ciencia - tecnología-desarrollo dependencia. Ed. Paidós, BsAs;

KLINE S. y ROSENBERG N. (1986) "An overview of innovation." In R. Landau \& N. Rosenberg (eds.), The Positive Sum Strategy: Harnessing Technology for Economic Growth. Washington, D.C.: National Academy Press, pp. 275-305.

KRAUSKOPF M.et al. (2007) "Link between science and innovation affects public policies in developing countries: The Chilean case". Scientometrics, Vol. 72, No. I 93-103

LANJOUW J. O., et al (1998), How to count patents and value intellectual property: the uses of patent renewal and application data, Journal of Industrial Economics, 46(4), 405-432.
LUGONES G, et al (20II). "Investigación científica e innovación tecnológica en Argentina : impacto de los fondos de la por Fernando Porta y Gustavo Lugones. - Ia Ed. - Bernal: Universidad Nacional de Quilmes. ISBN: 978-987-558-234-7

LUNDVALL, B.-Å. (1985). Product innovation and user-producer interaction. Aalborg: Aalborg University Press.

MARQUES, R and GONÇALVES NETO, C (2007) "The Brazilian system of innovation in biotechnology: a preliminary study" J.Tech Man Innov., vol 2; issue I; pag. 55 - 63

MARTÍNEZ VIDAL. C.(2002) La Escuela Latinoamericana de Pensamiento en Ciencia,Tecnología y Desarrollonotas de un Proyecto de Investigación. CTS+l: Revista lberoamericana de Ciencia, Tecnología, Sociedad e Innovación, ISSN I68I-5645, $\mathrm{N}^{\circ} .4,5-30$.

MEYER, M. (2000). "Does Science push technology? Patents citing scientific literature" en Research Policy nro. 29, págs. 409-434.

MIROWSKI, P. (201 I). "Science - Mart . Privatizing American Science" - Harvard University Pres - 20II;

NARIN, F. y NOMA, E. (1985) "Is technology becoming Science?" en Scientometrics, Vol. 7, Nros 3-6, págs 369-38I.

NARIN, F., HAMILTON, K., y OLIVASTRO, D. (1997), "The increasing linkage between US technology and public science”, en Research Policy, 26 (3) : 317-330.

NELSON, R. (1995). Recent Evolutionary Theorizing about Economic Change. Journal of Economic Literature, Volumen 23, Marzo 1995, pp.48-90.

NELSON, R.Y S. WINTER. (1982). An Evolutionary Theory of Economic Change. Harvard University Press.

NELSON, R., ed. (1993). National Systems of Innovation. Oxford University Press.

PERKO J. S. y NARIN F. "The Transfer of Public Science to Patented Technology: A Case Study in Agricultural Science" Journal of Technology Transfer Vol. 22 (3) 65-72, 1997

PISANO, G. (2006) "Science Business", Harvard Business School Press.

RULLANI, E. (2004). "El capitalismo cognitivo ¿un déjà- vu?," en O. Blondeau, et al., Capitalismo cognitivo, propiedad intelectual y creación colectiva (Madrid:Traficantes de sueños) http://sindominio.net/traficantes/editorial/capitalismocognitivo.htm consultado noviembre de $20 \mathrm{II}$ 
SÁBATO, J.Y BOTANA, N.(1970) "La ciencia y la tecnología en el desarrollo de América Latina”, en Herrera Amílcar y otros. América Latina: Ciencia y Tecnología en el desarrollo de la sociedad, Colección Tiempo latinoamericano, Editorial Universitaria SA, Santiago de Chile, 1970, pp.59-76.

SCHMAL R. et al (2010) Modelado de Procesos de Negocio para la Gestión de Patentes en Universidades). Información Tecnológica Vol. 2 I (6), I I3-124

TEUBAL, M. (1996). R\&D and Technology Policy at NICs as Learning Processes. World

VEGA-JURADO,j; FERNÁNDEZ DE LUCIO, I and HUANCA-LOPEZ, R. (2007) "iLa relación universidad - empresa en América Latina: apropiación incorrecta de modelos foráneos?" ; J.Techno.Manag.Innov.Vol 2, issue I, pag 97 - 109

ZAWISLAK, P.A. and G. DALMARCO. 20II ."The Silent Run: New Issues and Outcomes for University-Industry Relations in Brazil”.J.Techno.Manag.Innov.Vol 6, Issue II.

ZUKERFELD, M. (2010). Capitalismo y conocimiento. Materialismo cognitivo, propiedad intelectual y capitalismo informacional. - Tesis de Doctorado, FLACSO. 
J.Technol. Manag. Innov. 2012,Volume 7, Issue 2

ISSN: 07I8-2724. (http://www.jotmi.org)

Journal of Technology Management \& Innovation @ Universidad Alberto Hurtado, Facultad de Economía y Negocios. 